\title{
Effect of dietary neutral detergent fibre source on lambs growth, meat quality and biohydrogenation intermediates
}

\author{
José Santos-Silva $^{\mathrm{a}, \mathrm{b}, *}$, Alexandra Francisco ${ }^{\mathrm{a}, \mathrm{b}}$, Susana P. Alves ${ }^{\mathrm{b}, \mathrm{c}}$, Paula Portugal ${ }^{\mathrm{a}}$, \\ Teresa Dentinho $^{\mathrm{a}, \mathrm{b}}$, João Almeida ${ }^{\mathrm{a}}$, David Soldado ${ }^{\mathrm{d}}$, Eliana Jerónimo ${ }^{\mathrm{d}, \mathrm{e}}$, Rui J.B. Bessa ${ }^{\mathrm{b}, \mathrm{c}}$ \\ ${ }^{a}$ Instituto Nacional de Investigação Agrária e Veterinária, Fonte Boa, 2005 Vale de Santarém, Portugal

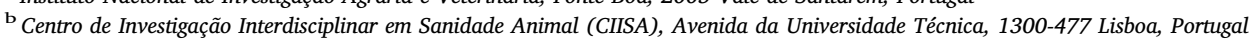 \\ ${ }^{\mathrm{c}}$ Faculdade de Medicina Veterinária, Universidade de Lisboa, Avenida da, Universidade Técnica, 1300-477 Lisboa, Portugal \\ ${ }^{\mathrm{d}}$ Centro de Biotecnologia Agrícola e Agro-Alimentar do Alentejo (CEBAL), Instituto Politécnico de Beja (IPBeja), 7801-908 Beja, Portugal \\ e Instituto de Ciências Agrárias e Ambientais Mediterrânicas (ICAAM), Universidade de Évora, 7000 Évora, Portugal
}

A R T I C L E I N F O

\section{Keywords:}

Lambs

Neutral Detergent Fibre

meat quality

biohydrogenation

fatty acid

trans10-shift

\begin{abstract}
A B S T R A C T
With this trial we have tested the effects of structural and chemical composition of neutral detergent fibre (NDF) of the diet on lamb fatty acid composition of meat and subcutaneous fat. Twenty lambs, were fed complete diets with low starch and similar NDF content of different origin (ground alfalfa or soybean hulls). Animal performance and product quality were not affected by treatments. Rumen $\mathrm{pH}$ increased and parakeratosis intensity decreased with the level of alfalfa in the diet. Increasing the alfalfa proportion in the diet decreased $t 10-18: 1$ $(P=.023)$, increased $t 11-18: 1(P=.003)$ and decreased the $t 10 / t 11$ ratio according to a quadratic pattern $(P=.020)$. Chemical composition and structure of the diet's fibrous fraction influenced the BI pattern of the final product. Forty percent of alfalfa in diet reduced the severity of $t 10$-shift, but for its full resolution, other factors should be considered including forage particle size and buffering capacity of the diet.
\end{abstract}

\section{Introduction}

Rumen biohydrogenation (BH) is a set of biochemical processes by which dietary unsaturated fatty acids (FA), mainly oleic (c9-18:1), linoleic (18:2 n-6) and linolenic acids (18:3 n-3), are isomerised, hydrogenated and ultimately converted to stearic acid (18:0) by rumen microbiota. The BH pathways yield variable amounts of FA with conjugated double bonds, cis and trans isomers which appear in meat and milk of ruminants. When fed with high-forage diets the main biohydrogenation intermediates (BI) deposited in their tissues are vaccenic (t11-18:1) and rumenic ( $c 9, t 11-18: 2)$ acids (Bessa, Alves, \& SantosSilva, 2015). Both $t 11-18: 1$ and $c 9, t 11-18: 2$ are considered healthy FA and nutritional strategies to enrich them in ruminant products have been extensively researched (Mapiye et al., 2015; Scollan et al., 2014). The supplementation of high-forage diets with C18 polyunsaturated FA is probably the most effective approach to achieve that goal (Bessa et al., 2015). However, in intensive production systems, meat ruminants are usually fed with low fibre and high concentrate cereal based diets, and under such conditions BH pathways change, and the t10-18:1 often becomes the overwhelming BI. Contrarily to t11-18:1 and $c 9, t 11-18: 2$, the $t 10-18: 1$ might exert deleterious health effect in the consumers (Chikwanha, Vahmani, Muchenje, Dugan, \& Mapiye, 2018; Hodgson, Wahlqvist, Boxall, \& Balazs, 1996). The occurrence of this shift of the BH pathways, hereafter $t 10$-shift, has also been associated with low milk fat syndrome in dairy cows (Griinari \& Bauman, 2001). The $t 10$-shift can be monitored using the ratio between $t 10-18: 1$ and $t 11-18: 1$ ( $t 10 / t 11$ ratio) in the rumen or tissues, and $t 10 / t 11$ ratio values above 1 clearly indicate the occurrence of the $t 10$-shift (Bessa et al., 2015). The causes of t10-shift are not known, but in the presence of high polyunsaturated FA (PUFA) concentration, the $t 10$-shift is associated to high dietary starch (Maia, Bessa, \& Wallace, 2009; Zened, Enjalbert, Nicot, \& Troegeler-Meynadier, 2013) and low rumen $\mathrm{pH}$ (Choi et al., 2005).

The need to reconcile intensive meat production systems with high nutritional value of meat lipids led us to raise the hypothesis that replacing cereals with low starch agro-industrial by-products in finishing diets would prevent the occurrence of the $t 10$-shift. Following this approach, we were able to reduce the $t 10 / t 11$ ratio in the milk of dairy sheep (Santos-Silva et al., 2016) and lamb meat (Francisco et al., 2017). However, we also reported unexpected results showing that diets with low starch and high fibre contents are compatible with the occurrence of $t 10$-shift in growing lambs (Costa et al., 2017). Thus, the proportion

\footnotetext{
* Corresponding author at: Instituto Nacional de Investigação Agrária e Veterinária, Fonte Boa, 2005 Vale de Santarém, Portugal.

E-mail address: jose.santossilva@iniav.pt (J. Santos-Silva).
} 
and nature of fibrous feeds in diets may play an important role in the occurrence of $t 10$-shift. We now hypothesized that the effects of neutral detergent fibre (NDF) on $\mathrm{BH}$ depend on its structural and chemical composition, and that the low fermentable NDF of alfalfa will be more effective in preventing the $t 10$-shift than the high fermentable NDF of soybean hulls. To test this hypothesis we conducted an experiment where lambs were fed diets with similar NDF content but differing in the origin (ie. ground alfalfa or soybean hulls) and evaluated the presence of BI in lamb tissues. In addition, possible collateral effects of diet on lamb growth performance and carcass and meat quality traits were evaluated.

\section{Materials and methods}

\subsection{Animals and management}

Twenty crossbred male lambs born in late winter of 2016 from Merino Branco ewes were used for the experiment, and animal handling followed the Directive 2010/63/EU (EU, 2010) concerning to the protection of animals used for scientific experiments. The lambs were born on a farm at Baixo Alentejo (Portugal) and reared with their dams on extensive pasture until weaning at about 60 days of age. Afterwards lambs were fed indoors with commercial concentrate for approximately four weeks. During that period, the lambs were dewormed for gastrointestinal and pulmonary parasites (Seponver ${ }^{\circledR}$ Plus, Ecuphar Veterinaria, Spain) and vaccinated against pasteurellosis and clostridial diseases (Heptavac ${ }^{\circledR}$ P Plus., MSD Animal Health, Portugal), and coccidiosis (Vecoxan ${ }^{\circledast} 2.5 \mathrm{mg} / \mathrm{ml}$, Esteve Veterinaria, Spain). Lambs were transported to Estação Zootécnica Nacional, Instituto Nacional de Investigação Agrária e Veterinária (EZN-INIAV), located at Vale de Santarém, Portugal in April, where the experiment was performed. Lambs were housed in individual pens with $1.25 \mathrm{~m}^{2}$ of area and wood shaving beds and had permanent access to clean water. The experiment started after 7 days of adaptation to the facilities and to the experimental period and lasted for 6 weeks. The average live weight of lambs at the beginning of the experiment was $24.6 \pm 2.21 \mathrm{~kg}$ (mean $\pm \mathrm{SD}$ ).

Three experimental diets were formulated and prepared at EZNINIAV feed mill facilities, attempting to obtain similar NDF, crude protein (CP) and ether extract (EE) proportions. The forage source of the diets was dehydrated pelleted alfalfa (Medicago sativa) that was balanced with different proportions of soybean hulls (Glicine max), and dehydrated citrus and beet pulps. The diets contained 200, 400 or $600 \mathrm{~g} / \mathrm{kg}$ DM of alfalfa were named as low (LA), medium (MA) and high (HA) alfalfa, respectively. All diets contained $6 \%$ soybean oil and were presented to the lambs milled $(<3 \mathrm{~mm})$. Lambs were randomly assigned to individual pens, with seven replicates for diets LA and MA and six replicates for the diet HA. Every day, at 9:00 am, feed refusals were weighed, registered and discarded and feed was provided at $110 \%$ of previous days intake. The chemical composition of the diets were averaged from three sets of analysis performed on pooled samples collected at the beginning, middle and end of the experimental period. Metabolizable energy was determined according to (Sauvant, Chapoutot, Peyraud, Meschy, \& Doreau, 2002) and the proximal and chemical compositions of the diets are presented in Table 1. During the experimental period, animals were weighed once a week before feeding.

\subsection{Slaughter procedures, carcasses evaluation and sample collection}

Lambs were slaughtered at the experimental abattoir of EZN-INAV, located $400 \mathrm{~m}$ from the lamb barn. Lambs were weighed before transport to the abattoir. After a maximum waiting period of $30 \mathrm{~min}$, lambs were stunned and exsanguinated. The rumen was emptied immediately and ruminal wall was evaluated for the occurrence of parakeratosis using a visual scale, as described by Tamate, Nagatani, Yoneya, Sakata, and Miura (1973). The whole rumen content was collected and
Table 1

Ingredients, chemical composition and fatty acid (FA) profile of the experimental diets.

\begin{tabular}{|c|c|c|c|}
\hline \multirow[t]{2}{*}{ Item } & \multicolumn{3}{|l|}{ Diets $^{1}$} \\
\hline & LA & MA & HA \\
\hline \multicolumn{4}{|l|}{ Ingredients, $\mathrm{g} / \mathrm{kg}$} \\
\hline Dehydrated alfalfa & 200 & 400 & 600 \\
\hline Soybean hulls & 338 & 235 & 90 \\
\hline Dehydrated citrus pulp & 70 & 56 & 30 \\
\hline Dehydrated beet pulp & 120 & 54 & 40 \\
\hline Soybean meal & 187 & 170 & 155 \\
\hline Soybean oil & 60 & 60 & 60 \\
\hline Calcium carbonate & 13 & 13 & 13 \\
\hline Sodium bicarbonate & 5 & 5 & 5 \\
\hline Salt & 4 & 4 & 4 \\
\hline Premix $^{2}$ & 3 & 3 & 3 \\
\hline \multicolumn{4}{|c|}{ Chemical composition, $\mathrm{g} / \mathrm{kg} \mathrm{DM}$} \\
\hline $\mathrm{DM}^{3}$ & 907.0 & 914.0 & 917.3 \\
\hline $\mathrm{CP}$ & 177.1 & 168.9 & 182.8 \\
\hline Ether extract & 79.3 & 76.3 & 71.0 \\
\hline FA & 75.9 & 72.1 & 74.8 \\
\hline Starch & 55.5 & 55.4 & 58.3 \\
\hline Sugar & 94.9 & 102.4 & 108.7 \\
\hline NDF & 437.4 & 432.5 & 417.8 \\
\hline $\mathrm{ADF}$ & 285.9 & 284.5 & 271.1 \\
\hline $\mathrm{ADL}$ & 25.4 & 36.8 & 40.7 \\
\hline ME (kJ/kg DM) & 13.35 & 13.01 & 12.81 \\
\hline \multicolumn{4}{|l|}{ FA profile, $\mathrm{g} / \mathrm{kg}$ total FA } \\
\hline $14: 0$ & 11.0 & 9.3 & 25.6 \\
\hline $16: 0$ & 127.1 & 123.5 & 123.7 \\
\hline 18:0 & 41.0 & 41.2 & 41.4 \\
\hline$c 9-18: 1$ & 229.0 & 224.7 & 225.1 \\
\hline$c 11-18: 1$ & 19.8 & 19.8 & 19.8 \\
\hline $18: 2 n-6$ & 512.7 & 516.8 & 505.1 \\
\hline $18: 3 n-3$ & 59.4 & 64.7 & 59.3 \\
\hline
\end{tabular}

1 LA- Low alfalfa; MA - Medium alfalfa; HA - High alfalfa.

2 Premix composition - Vit A - 4000000 UI; Vit D3 - 1100000 UI; Vit E 7.5 g/kg; Vit B1 and B2 - 250 mg/kg; Zn - 35 g/kg; Fe - 12.5 g/kg; Mn - 17.5 g/kg; I - 200 mg/kg; Co - 250 mg(kg; Se - $100 \mathrm{mg} / \mathrm{kg}$.

${ }^{3} \mathrm{~g} / \mathrm{kg}$ feed.

homogenized. A sample was strained through 4 layer of cheesecloth, resulting in an aliquot with about $80 \mathrm{ml}$ of rumen liquor, and its $\mathrm{pH}$ was immediately measured using a pH meter (Metrohm 744). An aliquot of $2 \mathrm{ml}$ of the strained rumen fluid was also preserved at $-20^{\circ} \mathrm{C}$ for volatile fatty acids (VFA) analysis.

Hot carcass weight (HCW) was measured immediately postslaughter and carcasses were kept in a refrigerated room at $10 \pm 1{ }^{\circ} \mathrm{C}$ for $24 \mathrm{~h}$ to prevent cold shortening. At $24 \mathrm{~h}$, carcasses were evaluated for conformation and fat cover, using the SEUROP classification system for lamb carcasses weighing $>13 \mathrm{~kg}$ (EC, 2011), and re-weighed to determine cold carcass weight (CCW). Carcasses were then chilled at $2 \pm 1{ }^{\circ} \mathrm{C}$ and $72 \mathrm{~h}$ after slaughter, kidney and kidney knob channel fat (KKCF) was removed, carcasses were split along the spine and the left sides were separated into eight joints that were individually weighed to estimate the proportion of the higher-priced joints (leg + chump + loin + ribs) as described by Santos-Silva, Bessa, and Santos-Silva (2002). Shoulders were vacuum-packed and frozen at $-20 \pm 1{ }^{\circ} \mathrm{C}$ until dissection to estimate the percentages of muscle, intermuscular and subcutaneous fat (ScF), and bone. Loin joints, containing the Longissimus lumborum muscle (LL), were vacuum-packed and kept for 4 days in a refrigerator at $2 \pm 1{ }^{\circ} \mathrm{C}$ before being frozen at $-20 \pm 1{ }^{\circ} \mathrm{C}$, for 30 days, until shear force and cooking loss determination. The Longissimus thoracis (LT) was isolated from rib joints. Colour coordinates were evaluated on a $1 \mathrm{~cm}$ chop after $1 \mathrm{~h}$ blooming at room temperature (day 0 of storage). Other LT chops with similar thickness were placed on polystyrene trays and over-wrapped with oxygen permeable polyvinyl chloride film, and maintained at $2{ }^{\circ} \mathrm{C}$ under continuous light for 
7 days. On day 7 of storage, meat colour was measured and each chop was vacuum-packed and stored at $-80{ }^{\circ} \mathrm{C}$ for lipid oxidation analysis. The epimysium was removed from the remaining portion of the LT, and the LT was ground with a food processor (Moulinex-123 A320R1) $(3 \times 5 \mathrm{~s})$ and vacuum-packed and stored at $-20^{\circ} \mathrm{C}$ until chemical analysis and $\mathrm{pH}$ determination. Subcutaneous fat $(\mathrm{ScF})$ samples were also collected for analysis of FA at the level of the 12th vertebra. Subcutaneous fat colour was evaluated on the inner surface of the leg, near the tail insertion.

\subsection{Analytical procedures}

\subsubsection{Feed, rumen and muscle chemical analysis}

Feed was analysed for dry matter (DM), crude protein (CP), ether extract (EE), starch, NDF, acid detergent fibre (ADF) and lignin (ADL) and lipid composition following the procedures described by Francisco et al. (2017). Rumen volatile FA profile was determined by gas chromatography, as described by Oliveira, Alves, Santos-Silva, and Bessa (2016).

Meat DM was measured on LT as described by Santos-Silva et al. (2016). Intramuscular lipids were extracted according to Folch, Lees, and Stanley (1957) as described by Jerónimo, Alves, Prates, SantosSilva, and Bessa (2009). Fatty acids from intramuscular and ScF lipids were transesterified according to Raes, De Smet, and Demeyer (2004), using sodium methoxide in methanol, followed by hydrochloric acid in methanol $(1: 1 \mathrm{v} / \mathrm{v})$. Fatty acid methyl esters were analysed using a Shimadzu GC 2010 Plus chromatograph (Shimadzu, Kyoto, Japan), equipped with a flame-ionization detector and fused silica capillary column (SP-2560 $(100 \mathrm{~m} \times 0.25 \mathrm{~mm}$ internal diameter $\times 0.20 \mu \mathrm{m}$ film thickness, Supelco, Bellefonte, PA, USA)). The injector and detector temperatures were $250{ }^{\circ} \mathrm{C}$ and $280^{\circ} \mathrm{C}$, respectively. The initial oven temperature of $50^{\circ} \mathrm{C}$ was held for $1 \mathrm{~min}$, increased at $50^{\circ} \mathrm{C} / \mathrm{min}$ to $150^{\circ} \mathrm{C}$ and held for $20 \mathrm{~min}$, increased at $1{ }^{\circ} \mathrm{C} / \mathrm{min}$ to $190^{\circ} \mathrm{C}$ and then increased at $2{ }^{\circ} \mathrm{C} / \mathrm{min}$ to $220^{\circ} \mathrm{C}$ and held for $40 \mathrm{~min}$. Helium was used as carrier gas at a flow rate of $1 \mathrm{ml} / \mathrm{min}$ and the split ratio was 50:1. Nonadecanoic acid (19:0) was used as internal standard to quantify muscle lipid FA methyl esters. Fatty acids were identified by comparison of the FAME retention times with those of authentic standards (FAME mix 37 components from Supelco Inc., Bellefont, PA, USA) and by comparison with published chromatograms (Alves \& Bessa, 2009; Vahmani, Rolland, Gzy, L, \& Dugan, 2016). In addition, a few FAME extracts of the muscle or ScF samples were hydrogenated (Alves et al., 2013) or derivatized into dimethyloxazoline derivatives (Alves \& Bessa, 2014) and subsequently analysed by electron impact mass spectrometry using a Shimadzu GC-MS QP2010 Plus (Shimadzu, Kyoto, Japan) system to reveal and identify more clearly the branched chain FA and the BI.

Lipid oxidative stability in meat was assessed by quantification of thiobarbituric acid reactive substances (TBARS) following the method described by Grau, Guardiola, Boatella, Barroeta, and Cordony (2000). Briefly, $2 \mathrm{~g}$ of meat was homogenized in $1 \mathrm{ml}$ of $0.3 \%$ aqueous ethylenediaminetetraacetic acid disodium salt (EDTA), $8 \mathrm{ml}$ of $5 \%$ aqueous trichloroacetic acid (TCA) and $5 \mathrm{ml}$ of $0.8 \%$ butylated hydroxytoluene (BHT) in hexane using an Ultra-Turrax T25 digital homogenizer (IKA Werbe GmbH \& Co. KG, Staufen, Germany) for $30 \mathrm{~s}$ at $19000 \mathrm{rpm}$. The homogenates were centrifuged for $5 \mathrm{~min}$ at $1400 \mathrm{~g}$ and the top hexane layer discarded. The bottom layer was filtered, and TCA was added to filtrate ( $5 \%$ aqueous) to make up a volume of $10 \mathrm{ml}$. A $2.5 \mathrm{ml}$ aliquot from the bottom layer was mixed with $1.5 \mathrm{ml}$ of $0.8 \%$ aqueous 2-thiobarbituric acid (TBA) and incubated at $70^{\circ} \mathrm{C}$ for $30 \mathrm{~min}$. Following incubation, the mixture was cooled under tap water and the absorbance was measured at $532 \mathrm{~nm}$ in a Double-beam UV-Vis scanning spectrophotometer (Helios alpha spectrophotometer, Thermo Scientific, Bremen, Germany). The 1,1,3,3 tetraethoxypropane standard curve was used for calculating the TBARS concentration and the results were expressed as mg of malonaldehyde (MDA) $/ \mathrm{kg}$ of meat.

\subsubsection{Meat quality determinations}

Meat quality was assessed based on colour, $\mathrm{pH}$, cooking loss and Warner-Bratzler shear force. The colour was measured using a Minolta CR-300 Chromometer (Konica Minolta, Japan) according to the CIELAB system, where $L^{*}$ is lightness, $a^{*}$ redness and $b^{*}$ yellowness. Determinations were made using the $\mathrm{C}$ illuminant and a $2^{\circ}$ standard observer. Colour saturation index (Chroma, $C^{*}$ ) was calculated as $\left(a^{* 2}+b^{* 2}\right)^{1 / 2}$ and the colour Hue angle $\left(H^{*}\right)$ as $\left(\tan -1\left(b^{*} / a^{*}\right) \times(180 /\right.$ $\pi)$ ) (AMSA, 2012). Meat colour variation $(\Delta \mathrm{E})$ during 7 days of storage were determined as follows: $\Delta \mathrm{E} \quad(7-0)=\left(\left(\Delta L^{*} \quad(7-0)\right)^{2}+\left(\Delta a^{*}\right.\right.$ $\left.(7-0))^{2}+\left(\Delta b^{*}(7-0)\right)^{2}\right)^{1 / 2}$. Muscle $\mathrm{pH}$ was determined according to ISO2917/1999. The $\mathrm{pH}$ was measured in a suspension of $5 \mathrm{~g}$ of minced meat in $50 \mathrm{ml}$ of a solution of potassium chloride $0.1 \mathrm{M}$, using a $\mathrm{pH}$ meter (Metrohm 744) equipped with a combined glass electrode. Meat cooking loss and Warner-Bratzler shear force were determined on LL, isolated from the left loin joints that were thawed for $20 \mathrm{~h}$ at $2 \pm 1{ }^{\circ} \mathrm{C}$ and cooked in a non ventilate electric oven, with the resistors covered by aluminium foil, at $170 \pm 5{ }^{\circ} \mathrm{C}$ until an internal temperature of $71 \pm 1{ }^{\circ} \mathrm{C}$ was reached. Longissimus lumborum temperatures were monitored individually with thermocouples (Thermometer, Omega RDXL4SD, Manchester, USA) and were cooled in a refrigerator at $2 \pm 1{ }^{\circ} \mathrm{C}$ and weighed after $20 \mathrm{~h}$ (AMSA, 2015). The cooking loss was determined as the difference between the weights of the intact LL, before and after cooking and expressed as a percentage of initial weight. To determine maximum shear force $(\mathrm{N}), 1 \mathrm{~cm}^{2}$ sections of LL muscle were sheared across the grain using a standard Stable Micro Systems Warner-Bratzler shear device, with $1.016 \mathrm{~mm}$ thickness blade, mounted in a Texture Analyser (TA.XT plus Texture Analyser, Stable Micro Systems, Surrey, UK) equipped with a compression load cell of $25 \mathrm{kgf}$. Sections were sheared using a crosshead speed of $2 \mathrm{~mm} / \mathrm{s}$. Data were collected using Texture Exponent version 6.1 software (Stable Micro Systems, Surrey, UK). The maximum force for each sample was averaged from a minimum of twelve to a maximum of 27 tests recorded.

\subsection{Statistical analysis}

Data were analysed using the MIXED procedure of SAS (SAS Institute Inc., Cary, NC). Individual lambs were the experimental unit and the level of significance was set at $P<.05$. Variance homogeneity was tested at $P=.01$, and when significant accommodated in the model using the group option within the repeated statement of the Proc Mixed.

Weekly BW data were subjected to regression analysis to estimate ADG (i.e. slopes). Daily DMI and weekly feed conversion ratio were analysed using a repeated measures model including diet as the main effect and day as the repeated measure, considering a first order autoregressive (AR(1)) covariance structure.

Body weight, rumen $\mathrm{pH}$, carcass and meat quality traits were analysed as a completely randomized experimental design, considering diet as the single fixed effect.

For FA composition, besides diet the model also included the adipose depot and the interaction between those two fixed effects, using an unstructured (UN) covariance structure.

Linear and quadratic polynomial orthogonal contrasts were used to test the effects of increasing dehydrated alfalfa in the diet. Slaughter weight, hot and cold carcass weights were adjusted to lamb initial weight; shoulder composition data were adjusted to hot carcass weight. When the effect of diet was significant, the least square means were compared, using pairwise Tukey's comparison test.

Spearman's rank coefficient was used to correlate rumen parakeratosis level and $\mathrm{pH}$, using the Graphpad Prism ${ }^{\circledR} 5.03$ software (Graphpad Software Inc., La Jolla, CA). 
Table 2

Effect of dietary neutral detergent fibre (NDF) composition on nutrient intake and growth performance of lambs.

\begin{tabular}{|c|c|c|c|c|c|}
\hline & \multicolumn{3}{|l|}{ Diets $^{1}$} & \multicolumn{2}{|l|}{$P$-value } \\
\hline & LA & MA & HA & Linear & Quad \\
\hline \multicolumn{6}{|l|}{ Intake, $\mathrm{g} / \mathrm{d}$} \\
\hline DM & $1352 \pm 49.8^{\mathrm{a}}$ & $1471 \pm 45.4^{\mathrm{ab}}$ & $1531 \pm 49.0^{\mathrm{b}}$ & 0.013 & 0.605 \\
\hline $\mathrm{CP}$ & $239 \pm 8.8^{\mathrm{a}}$ & $249 \pm 7.9^{\mathrm{a}}$ & $280 \pm 8.5^{\mathrm{b}}$ & 0.002 & 0.295 \\
\hline Sugar & $128 \pm 5.1^{\mathrm{a}}$ & $151 \pm 5.1^{\mathrm{b}}$ & $166 \pm 4.0^{c}$ & $<0.001$ & 0.591 \\
\hline Starch & $75.1 \pm 2.86^{\mathrm{a}}$ & $81.6 \pm 2.85^{\mathrm{a}}$ & $89.3 \pm 2.14^{\mathrm{b}}$ & $<0.001$ & 0.830 \\
\hline NDF & $591 \pm 22.2$ & $631 \pm 22.2$ & $640 \pm 15.2$ & 0.069 & 0.540 \\
\hline $\mathrm{ADF}$ & $386 \pm 14.2$ & $417 \pm 14.5$ & $415 \pm 10.0$ & 0.100 & 0.339 \\
\hline $\mathrm{ADL}$ & $34.6 \pm 1.43^{\mathrm{a}}$ & $49.5 \pm 1.73^{\mathrm{b}}$ & $62.1 \pm 1.54^{\mathrm{c}}$ & $<0.001$ & 0.554 \\
\hline $\mathrm{ME}(\mathrm{MJ} / \mathrm{d})$ & $18.06 \pm 0.810$ & $19.16 \pm 0.809$ & $19.63 \pm 0.552$ & 0.106 & 0.733 \\
\hline Total fatty acids & $107 \pm 4.0$ & $112 \pm 3.9$ & $109 \pm 2.6$ & 0.721 & 0.354 \\
\hline $14: 0$ & $1.16 \pm 0.049^{\mathrm{a}}$ & $1.06 \pm 0.049^{\mathrm{a}}$ & $2.73 \pm 0.082^{b}$ & $<0.001$ & $<0.001$ \\
\hline $16: 0$ & $13.6 \pm 0.49$ & $13.9 \pm 0.49$ & $13.5 \pm 0.32$ & 0.794 & 0.584 \\
\hline $18: 0$ & $4.40 \pm 0.162$ & $4.62 \pm 0.162$ & $4.51 \pm 0.107$ & 0.579 & 0.379 \\
\hline$c 9-18: 1$ & $24.5 \pm 0.89$ & $25.2 \pm 0.89$ & $24.5 \pm 0.58$ & 0.973 & 0.512 \\
\hline c11-18:1 & $2.12 \pm 0.078$ & $2.22 \pm 0.078$ & $2.16 \pm 0.051$ & 0.0 .685 & 0.350 \\
\hline $18: 2 n-6$ & $54.9 \pm 2.03$ & $57.9 \pm 2.02$ & $55.0 \pm 1.31$ & 0.984 & 0.215 \\
\hline $18: 3 n-3$ & $6.37 \pm 0.244^{\mathrm{a}}$ & $7.24 \pm 0.243^{\mathrm{b}}$ & $6.46 \pm 0.154^{\mathrm{a}}$ & 0.751 & 0.005 \\
\hline Initial BW, kg & $25.3 \pm 0.81$ & $24.9 \pm 0.81$ & $23.3 \pm 0.88$ & 0.114 & 0.532 \\
\hline Slaughter BW, kg & $36.4 \pm 0.98$ & $36.8 \pm 0.96$ & $37.5 \pm 1.09$ & 0.434 & 0.887 \\
\hline $\mathrm{ADG}, \mathrm{g} / \mathrm{d}$ & $282 \pm 10.9$ & $283 \pm 10.9$ & $304 \pm 11.8$ & 0.178 & 0.487 \\
\hline Feed conversion ratio ${ }^{2}$ & $4.57 \pm 0.266$ & $4.56 \pm 0.279$ & $5.02 \pm 0.290$ & 0.261 & 0.485 \\
\hline \multicolumn{6}{|l|}{ Rumen parameters } \\
\hline $\mathrm{pH}$ & $5.45 \pm 0.091^{\mathrm{a}}$ & $5.49 \pm 0.091^{\mathrm{a}}$ & $5.79 \pm 0.098^{b}$ & 0.023 & 0.281 \\
\hline \multicolumn{6}{|l|}{ Volatile fatty acids } \\
\hline Total, mmol/L & $74.4 \pm 2.80$ & $78.1 \pm 2.80$ & $67.2 \pm 3.97$ & 0.174 & 0.065 \\
\hline \multicolumn{6}{|l|}{ Molar percentages } \\
\hline $2: 0$ & $52.5 \pm 1.01^{\mathrm{ab}}$ & $54.8 \pm 1.01^{\mathrm{b}}$ & $51.1 \pm 1.10^{\mathrm{a}}$ & 0.377 & 0.028 \\
\hline $3: 0$ & $32.6 \pm 1.11$ & $29.8 \pm 1.11$ & $31.7 \pm 1.66$ & 0.665 & 0.140 \\
\hline iso- $4: 0$ & $4.01 \pm 0.860$ & $2.73 \pm 0.860$ & $3.52 \pm 0.447$ & 0.614 & 0.312 \\
\hline $4: 0$ & $10.4 \pm 0.81$ & $11.7 \pm 0.81$ & $12.1 \pm 1.62$ & 0.393 & 0.707 \\
\hline 2:0/3:0 ratio & $1.63 \pm 0.081$ & $1.86 \pm 0.081$ & $1.65 \pm 0.143$ & 0.898 & 0.075 \\
\hline
\end{tabular}

Means within a row with different superscripts differ $(P<.05)$.

1 LA- Low alfalfa; MA - Medium alfalfa; HA - High alfalfa.

$2 \mathrm{~kg}$ dry matter intake/ $\mathrm{kg}$ weight increase.

\section{Results}

\subsection{Intake and growth performance}

Daily feed intake and growth performance of lambs are presented in Table 2. Increasing alfalfa proportion in the diet linearly increased DM intake $(P=.013)$, ranging from $1352 \mathrm{~g} / \mathrm{d}$ for LA diet to $1531 \mathrm{~g} / \mathrm{d}$ for the HA diet. Intake of $\mathrm{CP}(P=.002)$, sugar $(P<.001)$, starch $(P<.001)$, ADL $(P<.001)$ and of 14:0 $(P<.001)$ were also higher for the HA than the LA diet. Quadratic effects were only observed for 14:0 and 18:3 n-3 intake. Diet did not influence growth rate of lambs nor feed conversion ratio, which averaged $290 \pm 38.5 \mathrm{~g}$ and $4.72 \pm 1.564$, respectively. The results of rumen parameters are presented in Table 2 . Rumen $\mathrm{pH}$ increased linearly $(P=.023)$ with the increase of alfalfa in the diet, and HA (5.79) had a higher value than the other two diets $(\approx 5.47)$. For volatile FA composition of rumen content, only a quadratic effect was observed for acetate $(P=.028)$, with a higher value for MA diet. The evaluation of parakeratosis lesions revealed that with the LA diet, $43 \%$ of the lambs presented moderate (level 2) and 57\% strong lesions (level 3) in rumen wall. In groups fed with MA and LA diets there were no lambs with level 3 lesions, $29 \%$ and $3 \%$ presented moderate lesions (level 2), $57 \%$ and $33 \%$ presented weak lesions (level 1) and 14\% and 33\% showed normal rumen wall (level 0), respectively.

\subsection{Carcass traits and meat quality of lambs}

Diet did not affect hot carcass weight, cold carcass weight or dressing percentage averaging $18.2 \pm 1.60 \mathrm{~kg}, 17.5 \pm 1.61 \mathrm{~kg}$ and $49.4 \pm 2.63 \%$, respectively (Table 3 ). For conformation, $15 \%$ of the carcasses were graded as U (very good); $70 \%$ as R (good) and $15 \%$ as O (fair). For fat cover, most of the carcasses (70\%) were graded in classes 2 or 3 (slight and average, respectively) and 30\% in class 4 (high). The percentage of higher priced cuts in carcasses were unaffected by alfalfa proportion in diets, averaging $54.5 \pm 0.96 \%$. Also, carcass composition did not differ among diets (Table 3). The mean KKCF content was $2.38 \pm 0.759 \%$ and the average tissue composition of the shoulder was $60.8 \pm 1.79 \%$ of muscle, $19.0 \pm 1.53 \%$ of bone, $11.1 \pm 1.36 \%$ of intermuscular fat and $9.1 \pm 2.12 \%$ of ScF. Meat quality results are presented in Table 3 and were generally not influenced by diet. Muscle $\mathrm{pH}$, intramuscular fat, cooking losses and shear force averaged $5.65 \pm 0.075, \quad 126.5 \pm 10.40 \mathrm{mg} / \mathrm{g} \quad \mathrm{DM}, \quad 30.1 \pm 2.36 \% \quad$ and $27.0 \pm 3.52 \mathrm{~N} / \mathrm{cm}^{2}$, respectively. Average values for meat colour parameters were $41.6 \pm 1.95$ for $L^{*}, 18.6 \pm 1.23$ for $a^{*}$, $5.71 \pm 0.951$ for $b^{*}, 19.5 \pm 1.37$ for $C^{*}$ and $17.0 \pm 2.15$ for $H^{*}$. Only a small linear increase was observed for for $L^{*}$ as the proportion of alfalfa increased $(P=.043)$. For colour, $L^{*}, a^{*}$ and $b^{*}$ averaged, $77.5 \pm 3.98,3.88 \pm 0.834$ and $5.48 \pm 1.35$, respectively. Colour stability of meat, determined after 7 days of storage was not influenced by diet, with an average $\Delta \mathrm{E}(7)$ of $6.4 \pm 1.84$. Meat lipid oxidation at 7 days of storage did not differ among diets, averaging $1.28 \pm 0.508 \mathrm{mg} \mathrm{MDA} / \mathrm{kg}$ of meat.

\subsection{Fatty acid composition of muscle and subcutaneous fat}

Total FA content did not differ among treatments and averaged 
Table 3

Effect of dietary neutral detergent fibre (NDF) composition on carcass traits and meat quality of lambs.

\begin{tabular}{|c|c|c|c|c|c|}
\hline & \multicolumn{3}{|l|}{ Diets $^{1}$} & \multicolumn{2}{|c|}{$P$-value } \\
\hline & LA & MA & HA & Linear & Quad \\
\hline \multicolumn{6}{|l|}{ Carcass traits } \\
\hline Hot carcass wt, $\mathrm{kg}$ & $18.1 \pm 0.36$ & $18.3 \pm 0.35$ & $18.1 \pm 0.40$ & 0.917 & 0.645 \\
\hline Cold carcass wt, kg & $17.4 \pm 0.37$ & $17.6 \pm 0.36$ & $17.4 \pm 0.41$ & 0.986 & 0.554 \\
\hline Dressing, \% & $49.9 \pm 1.00$ & $49.6 \pm 1.00$ & $48.5 \pm 1.12$ & 0.388 & 0.727 \\
\hline $\mathrm{KKCF}^{2}, \%$ & $2.37 \pm 0.311$ & $2.54 \pm 0.309$ & $2.22 \pm 0.347$ & 0.757 & 0.531 \\
\hline Higher priced cuts ${ }^{3}, \%$ & $55.1 \pm 0.36$ & $54.4 \pm 0.36$ & $54.1 \pm 0.40$ & 0.090 & 0.660 \\
\hline \multicolumn{6}{|l|}{ Shoulder composition (\%) } \\
\hline Muscle & $60.7 \pm 0.56$ & $60.4 \pm 0.56$ & $61.3 \pm 0.62$ & 0.508 & 0.421 \\
\hline Bone & $19.2 \pm 0.53$ & $18.5 \pm 0.53$ & $19.5 \pm 0.59$ & 0.779 & 0.201 \\
\hline Intermuscular fat & $11.1 \pm 0.41$ & $10.9 \pm 0.41$ & $11.3 \pm 0.46$ & 0.720 & 0.518 \\
\hline Subcutaneous fat & $8.94 \pm 0.695$ & $10.21 \pm 0.692$ & $7.90 \pm 0.778$ & 0.346 & 0.056 \\
\hline \multicolumn{6}{|l|}{ Subcutaneous fat colour ${ }^{4}$} \\
\hline$L^{*}$ & $79.6 \pm 1.44$ & $75.9 \pm 1.44$ & $76.7 \pm 1.56$ & 0.185 & 0.229 \\
\hline$a^{*}$ & $3.39 \pm 0.298$ & $4.14 \pm 0.298$ & $4.16 \pm 0.322$ & 0.097 & 0.330 \\
\hline$b^{*}$ & $5.40 \pm 0.530$ & $5.24 \pm 0.530$ & $5.84 \pm 0.573$ & 0.582 & 0.579 \\
\hline \multicolumn{6}{|l|}{ Longissimus muscle } \\
\hline $\mathrm{pH}$ & $5.65 \pm 0.027$ & $5.61 \pm 0.027$ & $5.69 \pm 0.030$ & 0.323 & 0.135 \\
\hline Intramuscular fat (mg/g DM) & $130.0 \pm 10.40$ & $122.1 \pm 10.40$ & $127.7 \pm 11.24$ & 0.881 & 0.611 \\
\hline Shear force, $\mathrm{N} / \mathrm{cm}^{5}$ & $28.7 \pm 1.27$ & $25.7 \pm 1.27$ & $26.48 \pm 1.37$ & 0.219 & 0.261 \\
\hline Cooking loss (\%) ${ }^{5}$ & $30.1 \pm 0.94$ & $30.0 \pm 0.94$ & $30.2 \pm 1.02$ & 0.982 & 0.856 \\
\hline \multicolumn{6}{|l|}{ Color $^{4}$} \\
\hline$L^{*}$ & $40.6 \pm 0.69^{a}$ & $41.4 \pm 0.69^{\mathrm{ab}}$ & $42.8 \pm 0.74^{\mathrm{b}}$ & 0.043 & 0.713 \\
\hline$a^{*}$ & $19.1 \pm 0.27$ & $18.2 \pm 0.27$ & $18.6 \pm 0.82$ & 0.613 & 0.217 \\
\hline$b^{*}$ & $5.78 \pm 0.359$ & $5.32 \pm 0.359$ & $6.06 \pm 0.388$ & 0.609 & 0.195 \\
\hline \multicolumn{6}{|l|}{ Colour stability (0 to $7 d)^{6}$} \\
\hline$\Delta \mathrm{E}$ & $7.01 \pm 0.709$ & $5.88 \pm 0.709$ & $6.32 \pm 0.766$ & 0.503 & 0.384 \\
\hline TBARS $^{7}$ & $1.22 \pm 0.200$ & $1.38 \pm 0.200$ & $1.23 \pm 0.216$ & 0.960 & 0.523 \\
\hline
\end{tabular}

${ }^{\mathrm{a}-\mathrm{b}}$ Means within a row with different superscripts differ $(\mathrm{P}<.05)$.

1 LA - Low alfalfa; MA - Medium alfalfa; HA - High alfalfa.

2 Kidney knob channel fat, expressed as \% of cold carcass weight.

${ }^{3}$ Leg + chump + loin + ribs, expressed as $\%$ of cold carcass weight.

4 At day 0 of storage.

5 At day 4 of storage.

6 Colour stability between days 0 and 7 of storage.

7 Thiobarbituric acid reactive substances (TBARS) at day 7 of storage, expressed as mg of malonaldehyde / kg of meat.

$666 \pm 69.0$ and $104 \pm 27.0 \mathrm{mg} / \mathrm{g} \mathrm{DM}$ for ScF and LT respectively (Table 4). The FA composition of ScF and LT are presented in Table 4 and BI are detailed in Table 5. Fatty acid composition of both ScF and LT were similarly affected by diet. In both tissues, the major FA was $c 9-18: 1$, followed by $16: 0$ and $18: 0$. The $c 9-18: 1$ and 18:0 proportions were not influenced by diet. The $c 9-18: 1$ averaged $282 \pm 27.9$ and $319 \pm 22.4 \mathrm{mg} / \mathrm{g}$ FA for ScF and LT respectively. The 18:0 proportions were $160 \mathrm{mg} / \mathrm{g} \mathrm{FA}$, for both tissues. The proportion of 16:0 linearly decreased $(P=.016)$ with alfalfa inclusion, from $208 \pm 1.2$ to $179 \pm 1.3 \mathrm{mg} / \mathrm{g}$ FA in ScF and from $240 \pm 4.7$ to $219 \pm 5.1 \mathrm{mg} / \mathrm{g} \mathrm{FA}$ in LT. The increase of alfalfa proportion in the diet linearly increased the sum of C18 FA $(P<.001)$, the sum of n-6 PUFA $(P=.015)$ and the tended to increase Total PUFA $(P=.05)$. These results were mainly influenced by $18: 2 \mathrm{n}-6$, which increased linearly $(P=.034)$ with the level alfalfa in the diet.

The sum of BI did not differ among diets but relevant differences were detected in the proportions of several individual BI. The major BI in the ScF and meat of lambs fed all the diets was the t10-18:1 followed by the $t 11-18: 1$. Increasing the alfalfa proportion in the diet led to linear decreases in $t 10-18: 1(P=.023)$ and $t 10, c 12-18: 2(P=.002)$, a quadratic decrease in the $t 10 / t 11$ ratio $(P=.020)$, and linear increases in t11-18:1 $(P=.003)$, t9-18:1 $(P=.012), t 15-18: 1 \quad(P=.017)$, c12-18:1 $\quad(P=.005), \quad t 16-18: 1 \quad(P=.016), \quad c 15-18: 1 \quad(P=.012)$, $c 9, t 11-18: 2(P=.003)$, the sum of CLAtt isomers $(P=.055)$ and the sum 18:2BI $(P<.001)$.

Fat depot location had a high impact on the FA composition. In a total of $48 \mathrm{FA}$ that were quantified, 42 were affected by tissue. Globally,
ScF when compared with LT intramuscular fat, presented lower proportions of saturated FA (SFA) $(P=.044)$, n-6 $(P<.001)$ and $\mathrm{n}-3$ $(P<.001)$ PUFA and higher proportions of terminal branched chain FA (TBCFA) $(\mathrm{P}<.001)$, non-terminal branched chain FA (NTBCFA) $(P<.001)$ and total cis-monounsaturated FA (cis-MUFA) $(P=.001)$ (Table 4). Subcutaneous fat presented higher proportions of all BI (Table 5), except $t 15$ and $c 12-18: 1$, which were not affected by depot location. The t10/t11 ratio was also not affected by the tissue type $(P=.263)$.

\section{Discussion}

Voluntary DM intake increased linearly with the level of dehydrated alfalfa in the diet (Table 2), but the Metabolizable Energy intake was not affected (results not shown). This suggests that DM intake was mainly regulated by energy satiety mechanisms. However, probably the growth rate of the lambs for all diets was below their genetic growth potential (Costa et al., 2017), and so other regulatory mechanisms of intake would likely be involved.

The rumen $\mathrm{pH}$ was quite low (bellow 5.8) for all diets suggesting the occurrence of sub-acute rumen acidosis. Such low rumen $\mathrm{pH}$ values are favoured by the fact that complete diets are fed ground, and thus the small forage particle size did not properly stimulate rumination and salivation. In practical ruminant nutrition, the effects of rumen $\mathrm{pH}$ are often confounded with that of dietary content of starch and other high fermentable carbohydrates. Moreover, the low rumen $\mathrm{pH}$ values observed were consistent with the severity of parakeratosis lesions on 
Table 4

Effect of dietary neutral detergent fibre (NDF) composition on lipids and fatty acid (FA) profile (g/100 g of total FA) in Longissimus thoracis muscle of lambs.

\begin{tabular}{|c|c|c|c|c|c|c|c|c|c|c|}
\hline & \multicolumn{3}{|c|}{ Subcutaneous fat } & \multicolumn{3}{|c|}{ Intramuscular fat } & \multicolumn{4}{|c|}{$P$ values } \\
\hline & \multirow[t]{2}{*}{$\mathrm{LA}^{1}$} & \multirow[t]{2}{*}{$\mathrm{MA}^{2}$} & \multirow[t]{2}{*}{$\mathrm{HA}^{3}$} & \multirow[t]{2}{*}{$\mathrm{LA}^{1}$} & \multirow[t]{2}{*}{$\mathrm{MA}^{2}$} & \multirow[t]{2}{*}{$\mathrm{HA}^{3}$} & \multicolumn{2}{|c|}{ Diet contrast } & \multirow[t]{2}{*}{ Depot } & \multirow[t]{2}{*}{ Diet* depo } \\
\hline & & & & & & & Linear & Quad. & & \\
\hline $\begin{array}{l}\text { FA, mg/g DM } \\
\text { FA profile } \\
\text { LC-SFA }^{4}\end{array}$ & $708 \pm 24.6$ & $647 \pm 24.6$ & $641 \pm 26.5$ & $106 \pm 10.3$ & $94 \pm 10.3$ & $112 \pm 11.1$ & 0.131 & 0.209 & $<0.001$ & 0.181 \\
\hline $10: 0$ & $0.47 \pm 0.059$ & $0.23 \pm 0.059$ & $0.38 \pm 0.063$ & $0.77 \pm 0.073$ & $0.67 \pm 0.073$ & $0.64 \pm 0.078$ & 0.116 & 0.049 & $<0.001$ & 0.410 \\
\hline $12: 0$ & $0.61 \pm 0.046$ & $0.46 \pm 0.046$ & $0.51 \pm 0.050$ & $0.62 \pm 0.053$ & $0.69 \pm 0.053$ & $0.63 \pm 0.058$ & 0.451 & 0.691 & 0.003 & 0.059 \\
\hline $14: 0$ & $20.9 \pm 1.85$ & $15.8 \pm 1.85$ & $16.3 \pm 2.00$ & $17.9 \pm 0.76$ & $19.0 \pm 0.76$ & $16.9 \pm 0.83$ & 0.068 & 0.631 & 0.828 & 0.109 \\
\hline $15: 0$ & $6.78 \pm 1.193$ & $8.06 \pm 1.193$ & $5.55 \pm 1.289$ & $2.71 \pm 0.126$ & $2.74 \pm 0.126$ & $2.66 \pm 0.136$ & 0.478 & 0.207 & $<0.001$ & 0.406 \\
\hline $16: 0$ & $208 \pm 12.2$ & $169 \pm 12.2$ & $179 \pm 13.2$ & $240 \pm 4.7$ & $237 \pm 4.7$ & $219 \pm 5.1$ & 0.016 & 0.298 & $<0.001$ & 0.157 \\
\hline $17: 0$ & $19.1 \pm 2.74$ & $23.6 \pm 2.74$ & $19.1 \pm 2.96$ & $9.5 \pm 0.46$ & $8.9 \pm 0.46$ & $8.9 \pm 0.50$ & 0.888 & 0.237 & $<0.001$ & 0.393 \\
\hline $18: 0$ & $156 \pm 14.8$ & $149 \pm 14.8$ & $176 \pm 16.0$ & $158 \pm 6.2$ & $157 \pm 6.2$ & $165 \pm 6.7$ & 0.260 & 0.292 & 0.937 & 0.731 \\
\hline $20: 0$ & $0.77 \pm 0.067$ & $0.78 \pm 0.067$ & $0.93 \pm 0.073$ & $0.76 \pm 0.035$ & $0.74 \pm 0.035$ & $0.82 \pm 0.037$ & 0.058 & 0.209 & 0.213 & 0.663 \\
\hline sum & $413 \pm 8.0$ & $368 \pm 25.4$ & $398 \pm 27.5$ & $431 \pm 3.5$ & $425 \pm 8.0$ & $414 \pm 8.7$ & 0.324 & 0.289 & 0.044 & 0.359 \\
\hline \multicolumn{11}{|l|}{ T-BCFA $^{5}$} \\
\hline iso-14:0 & $0.02 \pm 0.054$ & $0.13 \pm 0.054$ & $0.02 \pm 0.058$ & $0.23 \pm 0.044$ & $0.26 \pm 0.044$ & $0.28 \pm 0.048$ & 0.614 & 0.191 & $<0.001$ & 0.401 \\
\hline iso-15:0 & $1.13 \pm 0.123$ & $1.16 \pm 0.123$ & $1.23 \pm 0.133$ & $0.58 \pm 0.089$ & $0.66 \pm 0.089$ & $0.70 \pm 0.096$ & 0.470 & 0.994 & $<0.001$ & 0.938 \\
\hline anteiso-15:0 & $1.99 \pm 0.150$ & $1.83 \pm 0.150$ & $1.59 \pm 0.162$ & $0.91 \pm 0.085$ & $0.86 \pm 0.085$ & $0.89 \pm 0.091$ & 0.188 & 0.997 & $<0.001$ & 0.167 \\
\hline iso-16:0 & $1.90 \pm 0.281$ & $2.39 \pm 0.281$ & $1.64 \pm 0.304$ & $0.94 \pm 0.068$ & $0.92 \pm 0.068$ & $0.98 \pm 0.073$ & 0.630 & 0.137 & $<0.001$ & 0.154 \\
\hline iso- $17: 0$ & $2.63 \pm 0.148$ & $2.67 \pm 0.148$ & $2.88 \pm 0.159$ & $1.85 \pm 0.127$ & $1.91 \pm 0.127$ & $2.20 \pm 0.137$ & 0.137 & 0.522 & $<0.001$ & 0.745 \\
\hline anteiso-17:0 & $7.27 \pm 1.120$ & $8.79 \pm 1.120$ & $6.45 \pm 1.210$ & $3.02 \pm 0.195$ & $2.73 \pm 0.195$ & $2.99 \pm 0.211$ & 0.623 & 0.256 & $<0.001$ & 0.300 \\
\hline Sum & $14.9 \pm 1.52$ & $17.0 \pm 1.52$ & $13.8 \pm 1.64$ & $7.5 \pm 0.53$ & $7.3 \pm 0.53$ & $8.0 \pm 0.57$ & 0.814 & 0.334 & $<0.001$ & 0.230 \\
\hline \multicolumn{11}{|l|}{ NT-BCFA ${ }^{6}$} \\
\hline $14: 0-\mathrm{Me}^{7}$ & $5.74 \pm 1.523$ & $7.21 \pm 1.523$ & $4.41 \pm 1.645$ & $0.52 \pm 0.060$ & $0.47 \pm 0.060$ & $0.39 \pm 0.065$ & 0.524 & 0.270 & $<0.001$ & 0.490 \\
\hline $16: 0-\mathrm{Me}^{8}$ & $11.0 \pm 2.96$ & $15.2 \pm 2.96$ & $10.2 \pm 3.20$ & $1.43 \pm 0.140$ & $1.34 \pm 0.140$ & $1.15 \pm 0.151$ & 0.814 & 0.223 & $<0.001$ & 0.479 \\
\hline Sum & $16.7 \pm 4.47$ & $22.4 \pm 4.47$ & $14.6 \pm 4.83$ & $1.9 \pm 0.19$ & $1.8 \pm 0.19$ & $1.5 \pm 0.20$ & 0.709 & 0.237 & $<0.001$ & 0.492 \\
\hline \multicolumn{11}{|l|}{ cis-MUFA $^{9}$} \\
\hline$c 9-14: 1$ & $0.49 \pm 0.069$ & $0.44 \pm 0.069$ & $0.33 \pm 0.075$ & $0.40 \pm 0.042$ & $0.47 \pm 0.042$ & $0.38 \pm 0.045$ & 0.190 & 0.358 & 0.962 & 0.287 \\
\hline$c 7-16: 1$ & $2.86 \pm 0.173$ & $2.80 \pm 0.173$ & $2.94 \pm 0.187$ & $2.06 \pm 0.096$ & $2.09 \pm 0.096$ & $2.16 \pm 0.103$ & 0.616 & 0.699 & $<0.001$ & 0.880 \\
\hline$c 9-16: 1$ & $8.95 \pm 0.731$ & $7.19 \pm 0.731$ & $7.15 \pm 0.790$ & $10.7 \pm 0.666$ & $10.8 \pm 0.666$ & $9.26 \pm 0.719$ & 0.082 & 0.991 & $<0.001$ & 0.197 \\
\hline$c 9-17: 1$ & $7.10 \pm 1.866$ & $10.8 \pm 1.87$ & $6.49 \pm 2.016$ & $4.26 \pm 0.218$ & $4.27 \pm 0.218$ & $4.05 \pm 0.236$ & 0.766 & 0.096 & 0.002 & 0.278 \\
\hline$c 9-18: 1^{10}$ & $276 \pm 10.9$ & $290 \pm 10.9$ & $280 \pm 11.7$ & $317 \pm 8.9$ & $324 \pm 8.9$ & $316 \pm 9.6$ & 0.890 & 0.342 & $<0.001$ & 0.889 \\
\hline$c 11-18: 1$ & $10.2 \pm 0.37$ & $10.3 \pm 0.37$ & $10.3 \pm 0.40$ & $11.8 \pm 0.43$ & $10.6 \pm 0.43$ & $11.1 \pm 0.47$ & 0.553 & 0.344 & 0.006 & 0.159 \\
\hline Sum & $458 \pm 10.4$ & $462 \pm 10.4$ & $455 \pm 11.3$ & $439 \pm 8.5$ & $432 \pm 8.5$ & $431 \pm 9.2$ & 0.642 & 0.920 & 0.001 & 0.772 \\
\hline \multicolumn{11}{|l|}{ n-6 PUFA } \\
\hline $18: 2 n-6$ & $53.6 \pm 4.12$ & $62.2 \pm 4.12$ & $68.3 \pm 4.45$ & $74.0 \pm 5.98$ & $85.0 \pm 5.98$ & $90.2 \pm 6.46$ & 0.034 & 0.715 & $<0.001$ & 0.933 \\
\hline $18: 3 n-6$ & $0.23 \pm 0.024$ & $0.20 \pm 0.024$ & $0.25 \pm 0.026$ & $0.44 \pm 0.044$ & $0.42 \pm 0.044$ & $0.57 \pm 0.047$ & 0.106 & 0.111 & $<0.001$ & 0.261 \\
\hline $20: 2 n-6$ & $0.35 \pm 0.073$ & $0.52 \pm 0.073$ & $0.43 \pm 0.078$ & $0.65 \pm 0.053$ & $0.63 \pm 0.053$ & $0.62 \pm 0.058$ & 0.812 & 0.371 & $<0.001$ & 0.173 \\
\hline $20: 4 n-6$ & $1.11 \pm 0.154$ & $1.09 \pm 0.154$ & $1.44 \pm 0.167$ & $11.7 \pm 1.41$ & $11.4 \pm 1.41$ & $12.5 \pm 1.53$ & 0.572 & 0.604 & $<0.001$ & 0.930 \\
\hline Sum & $56.0 \pm 4.26$ & $64.7 \pm 4.26$ & $71.2 \pm 4.60$ & $89.2 \pm 7.39$ & $99.8 \pm 7.39$ & $106.5 \pm 7.98$ & 0.048 & 0.819 & $<0.001$ & 0.968 \\
\hline \multicolumn{11}{|l|}{ n-3 PUFA } \\
\hline $18: 3 n-3$ & $7.18 \pm 0.515$ & $8.32 \pm 0.515$ & $8.58 \pm 0.556$ & $5.85 \pm 0.413$ & $6.53 \pm 0.413$ & $6.73 \pm 0.446$ & 0.099 & 0.544 & $<0.001$ & 0.402 \\
\hline $20: 3 n-3$ & $0.36 \pm 0.014$ & $0.35 \pm 0.024$ & $0.45 \pm 0.025$ & $1.27 \pm 0.132$ & $1.20 \pm 0.132$ & $1.38 \pm 0.420$ & 0.336 & 0.312 & $<0.001$ & 0.917 \\
\hline $20: 5 n-3$ & $0.09 \pm 0.022$ & $0.09 \pm 0.022$ & $0.12 \pm 0.024$ & $1.18 \pm 0.110$ & $1.14 \pm 0.110$ & $1.28 \pm 0.119$ & 0.416 & 0.444 & $<0.001$ & 0.764 \\
\hline $22: 5 n-3$ & $0.68 \pm 0.078$ & $0.62 \pm 0.078$ & $0.81 \pm 0.085$ & $2.68 \pm 0.238$ & $2.51 \pm 0.238$ & $2.87 \pm 0.257$ & 0.401 & 0.220 & $<0.001$ & 0.889 \\
\hline $22: 6 n-3$ & $0.07 \pm 0.031$ & $0.10 \pm 0.031$ & $0.13 \pm 0.033$ & $0.41 \pm 0.057$ & $0.45 \pm 0.057$ & $0.42 \pm 0.061$ & 0.587 & 0.697 & $<0.001$ & 0.698 \\
\hline sum & $8.3 \pm 0.58$ & $9.1 \pm 0.58$ & $9.6 \pm 0.63$ & $10.1 \pm 0.63$ & $10.6 \pm 0.63$ & $11.3 \pm 0.68$ & 0.114 & 0.879 & $<0.001$ & 0.596 \\
\hline Total PUFA $^{11}$ & $64.0 \pm 4.82$ & $73.9 \pm 4.82$ & $80.9 \pm 5.21$ & $99.3 \pm 7.86$ & $110 \pm 7.86$ & $118 \pm 8.49$ & 0.050 & 0.822 & $<0.001$ & 0.983 \\
\hline C18 FA ${ }^{12}$ & $675 \pm 11.8$ & $683 \pm 20.5$ & $716 \pm 5.4$ & $675 \pm 5.0$ & $680 \pm 5.0$ & $696 \pm 5.4$ & 0.001 & 0.442 & 0.396 & 0.410 \\
\hline
\end{tabular}

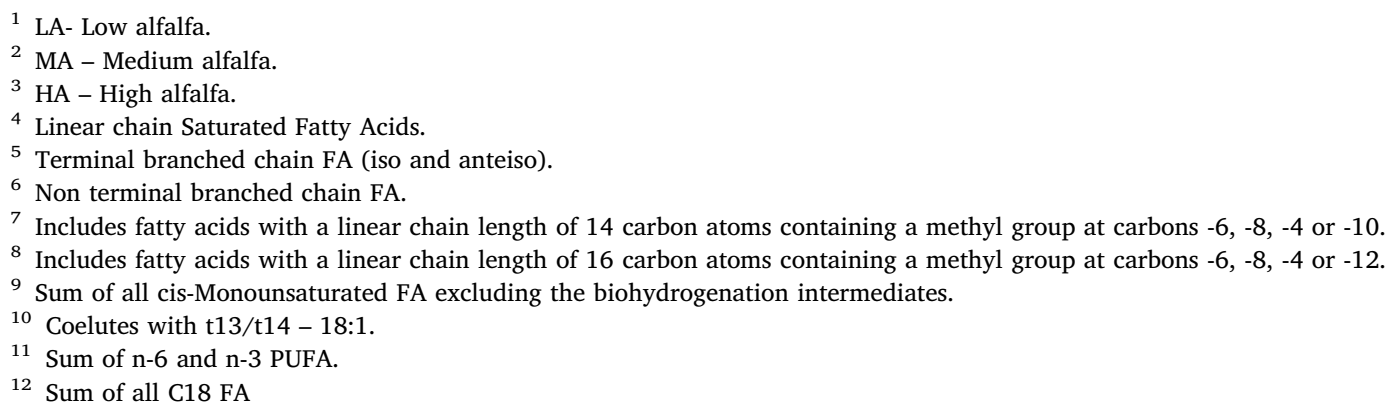

rumen mucosa $(\rho=-0.56 ; P=.001)$, that can be a better indicator of acidotic rumen conditions over the experimental period than just a single measurement of $\mathrm{pH}$ rumen after slaughter (Kleen, Hooijer, Rehage, \& Noordhuizen, 2003).

Experimental diets did not affect carcass or meat quality parameters. The results obtained in the present trial were in agreement with other reports for Merino Branco lambs reared in similar conditions and with similar carcass weights (Santos-Silva, Mendes, Portugal, \& Bessa, 2004). In LT, the average values obtained three days after slaughter for lightness $\left(L^{*}\right)$ were above 40 and for redness $\left(a^{*}\right)$ above 18 
Table 5

Effect of dietary neutral detergent fibre (NDF) composition on C18 biohydrogenation intermediates (BI) ( $\mathrm{g} / 100 \mathrm{~g}$ of total fatty acids) present in LM of lambs.

\begin{tabular}{|c|c|c|c|c|c|c|c|c|c|c|}
\hline & \multicolumn{3}{|l|}{ Subcutaneous fat } & \multicolumn{3}{|l|}{ Intramuscular fat } & \multicolumn{4}{|l|}{$P$ values } \\
\hline & \multirow[t]{2}{*}{$\mathrm{LA}^{1}$} & \multirow[t]{2}{*}{$\mathrm{MA}^{2}$} & \multirow[t]{2}{*}{$\mathrm{HA}^{3}$} & \multirow[t]{2}{*}{$\mathrm{LA}^{1}$} & \multirow[t]{2}{*}{$\mathrm{MA}^{2}$} & \multirow[t]{2}{*}{$\mathrm{HA}^{3}$} & \multicolumn{2}{|c|}{ Diet contrast } & \multirow[t]{2}{*}{ Depot } & \multirow[t]{2}{*}{ Diet*depot } \\
\hline & & & & & & & Linear & Quad. & & \\
\hline \multicolumn{11}{|l|}{$18: 1$ isomers } \\
\hline$t 4-$ & $0.62 \pm 0.054$ & $0.66 \pm 0.054$ & $0.62 \pm 0.058$ & $0.18 \pm 0.018$ & $0.17 \pm 0.018$ & $0.16 \pm 0.019$ & 0.907 & 0.472 & $<0.001$ & 0.885 \\
\hline$t 6-/ t 7-/ t 8$ & $5.99 \pm 0.439$ & $6.26 \pm 0.439$ & $6.93 \pm 0.475$ & $3.67 \pm 0.193$ & $3.53 \pm 0.193$ & $4.23 \pm 0208$ & 0.040 & 0.306 & $<0.001$ & 0.803 \\
\hline t9- & $3.60 \pm 0.282$ & $4.39 \pm 0.282$ & $5.35 \pm 0.671$ & $2.47 \pm 0.282$ & $2.59 \pm 0.101$ & $3.23 \pm 0.305$ & 0.012 & 0.504 & $<0.001$ & 0.350 \\
\hline$t 10-$ & $104.6 \pm 15.79$ & $75.1 \pm 10.50$ & $65.0 \pm 17.06$ & $60.9 \pm 7.99$ & $37.8 \pm 5.60$ & $35.3 \pm 8.63$ & 0.023 & 0.268 & 0.001 & 0.866 \\
\hline$t 11-$ & $12.3 \pm 1.26$ & $22.7 \pm 3.71$ & $37.4 \pm 8.06$ & $9.1 \pm 0.13$ & $16.7 \pm 2.13$ & $23.2 \pm 4.01$ & 0.003 & 0.804 & 0.040 & 0.462 \\
\hline$t 12-$ & $8.33 \pm 0.646$ & $8.75 \pm 0.646$ & $9.47 \pm 0.698$ & $5.20 \pm 0.299$ & $5.00 \pm 0.299$ & $5.79 \pm 0.323$ & 0.110 & 0.473 & $<0.001$ & 0.802 \\
\hline$t 15-$ & $3.04 \pm 0.444$ & $3.53 \pm 0.444$ & $3.92 \pm 0.480$ & $2.61 \pm 0.198$ & $3.06 \pm 0.198$ & $3.56 \pm 0.214$ & 0.017 & 0.955 & 0.168 & 0.985 \\
\hline$c 12-$ & $6.65 \pm 0.743$ & $9.27 \pm 1.790$ & $10.44 \pm 1.934$ & $4.80 \pm 0.743$ & $6.93 \pm 0.743$ & $8.40 \pm 0.803$ & 0.005 & 0.645 & 0.055 & 0.975 \\
\hline$c 13-$ & $1.69 \pm 0.102$ & $1.48 \pm 0.102$ & $1.37 \pm 0.110$ & $1.26 \pm 0.089$ & $1.07 \pm 0.089$ & $1.15 \pm 0.096$ & 0.107 & 0.389 & $<0.001$ & 0.280 \\
\hline$t 16-^{4}$ & $2.91 \pm 0.357$ & $3.56 \pm 0.357$ & $4.08 \pm 0.386$ & $1.56 \pm 0.238$ & $2.21 \pm 0.238$ & $2.46 \pm 0.257$ & 0.016 & 0.683 & $<0.001$ & 0.785 \\
\hline$c 15-$ & $1.84 \pm 0.124$ & $1.62 \pm 0.124$ & $1.40 \pm 0.134$ & $1.03 \pm 0.092$ & $0.97 \pm 0.092$ & $0.88 \pm 0.099$ & 0.012 & 0.938 & $<0.001$ & 0.434 \\
\hline Sum & $152 \pm 12.6$ & $137 \pm 12.6$ & $146 \pm 13.6$ & $92.8 \pm 6.16$ & $80.0 \pm 6.16$ & $88.2 \pm 6.66$ & 0.704 & 0.338 & $<0.001$ & 0.991 \\
\hline \multicolumn{11}{|l|}{$18: 2$ isomers } \\
\hline$t 8, c 13-$ & $0.11 \pm 0.018$ & $0.14 \pm 0.018$ & $0.14 \pm 0.0 .019$ & $0.10 \pm 0.013$ & $0.12 \pm 0.013$ & $0.12 \pm 0.014$ & 0.372 & 0.538 & 0.018 & 0.644 \\
\hline$c 9, t 13 / c 9, t 14-^{6}$ & $0.39 \pm 0.039$ & $0.43 \pm 0.039$ & $0.42 \pm 0.042$ & $0.32 \pm 0.0 .029$ & $0.31 \pm 0.029$ & $0.30 \pm 0.031$ & 0.870 & 0.780 & $<0.001$ & 0.511 \\
\hline$c 9, t 11^{7}$ & $4.79 \pm 0.821$ & $9.06 \pm 0.210$ & $10.91 \pm 0.186$ & $3.52 \pm 0.332$ & $5.99 \pm 0.821$ & $7.42 \pm 1.857$ & 0.003 & 0.346 & 0.019 & 0.431 \\
\hline$t 9, c 11-$ & $0.85 \pm 0.281$ & $1.26 \pm 0.281$ & $0.58 \pm 0.303$ & $0.58 \pm 0.058$ & $0.37 \pm 0.058$ & $0.29 \pm 0.060$ & 0.203 & 0.195 & 0.011 & 0.261 \\
\hline$c 9, t 15 / c 9, t 12$ & $0.07 \pm 0.015$ & $0.10 \pm 0.015$ & $0.10 \pm 0.016$ & $0.05 \pm 0.007$ & $0.06 \pm 0.007$ & $0.06 \pm 0.007$ & 0.234 & 0.370 & $<0.001$ & 0.334 \\
\hline$t 10, c 15-/ t 11, c 15-$ & $4.10 \pm 0.562$ & $3.48 \pm 0.562$ & $3.07 \pm 0.608$ & $2.72 \pm 0.299$ & $2.07 \pm 0.299$ & $1.72 \pm 0.323$ & 0.119 & 0.811 & $<0.001$ & 0.992 \\
\hline CLA $t / t^{5}$ & $0.84 \pm 0.066$ & $0.86 \pm 0.066$ & $1.13 \pm 0.071$ & $0.59 \pm 0.060$ & $0.53 \pm 0.060$ & $0.63 \pm 0.065$ & 0.055 & 0.156 & $<0.001$ & 0.060 \\
\hline$t 10, c 12-$ & $1.59 \pm 0.216$ & $1.24 \pm 0.216$ & $0.89 \pm 0.234$ & $0.93 \pm 0.102$ & $0.54 \pm 0.102$ & $0.44 \pm 0.110$ & 0.002 & 0.631 & $<0.001$ & 0.767 \\
\hline$t 11, c 13-^{8}$ & $0.02 \pm 0.002^{b}$ & $0.03 \pm 0.002^{b c}$ & $0.04 \pm 0.003^{c}$ & $0.01 \pm 0.003^{\mathrm{a}}$ & $0.01 \pm 0.003^{\mathrm{ab}}$ & $0.01 \pm 0.003^{\mathrm{ab}}$ & 0.008 & 0.676 & $<0.001$ & 0.008 \\
\hline Sum & $8.07 \pm 1.298$ & $12.4 \pm 1.30$ & $13.5 \pm 1.40$ & $5.62 \pm 0.817$ & $7.43 \pm 0.817$ & $8.76 \pm 0.883$ & $<0.001$ & 0.334 & $<0.001$ & 0.448 \\
\hline \multicolumn{11}{|l|}{$18: 3$ isomer } \\
\hline$c 9, t 11, c 15-{ }^{9}$ & $0.33 \pm 0.061$ & $0.47 \pm 0.061$ & $0.68 \pm 0.066$ & $1.20 \pm 0.120$ & $1.07 \pm 0.120$ & $1.35 \pm 0.130$ & 0.068 & 0.289 & $<0.001$ & 0.080 \\
\hline $\mathrm{BI}$ & $181 \pm 13.1$ & $172 \pm 13.1$ & $182 \pm 14.1$ & $119 \pm 6.8$ & $106 \pm 6.8$ & $116 \pm 7.4$ & 0.904 & 0.278 & $<0.001$ & 0.985 \\
\hline$t 10 / t 11$ ratio & $10.0 \pm 2.63$ & $3.8 \pm 0.62$ & $4.4 \pm 2.84$ & $7.8 \pm 1.56$ & $2.5 \pm 0.62$ & $2.5 \pm 0.69$ & 0.026 & 0.020 & 0.259 & 0.959 \\
\hline
\end{tabular}

abc Within the same row, means with different superscripts are statistically different $(\mathrm{P}<.05)$.

1 LA - Low alfalfa.

2 MA - Medium alfalfa.

${ }^{3}$ HA - High alfalfa.

${ }^{4}$ Coelutes with $c 14-18: 1$.

5 Sum of trans/trans conjugated linoleic acid isomers.

6 Coelutes with 17-cyclo and t8,c12-18:2.

7 Includes $t 7, c 9-18: 2$ as minor isomer.

${ }^{8}$ Coelutes with $21: 0 ;{ }^{9}$ coelutes with $20: 3 n-9$.

in all treatments, and would be likely acceptable by consumers (Khliji, van de Ven, Lamb, Lanza, \& Hopkins, 2010). The colour of meat and fat from ruminants may be affected by diet, and animals fed a high proportion of forage can have darker and redder meat with more yellow fat compared to others raised in confinement and fed with concentratebased diets (Priolo, Micol, \& Agabriel, 2001; Ripoll, Albertí, \& Joy, 2012). In addition, in the present trial, the lambs were reared in confinement and were fed with diets with high levels of concentrate (40 to $80 \%$ ). Moreover, the forage component was dehydrated alfalfa, which has much lower content of carotenoids than fresh grasses due to changes induced by the conservation process (Nozière et al., 2006).

The average shear force obtained in the present trial is comparable to others reported for Merino Branco LL processed in similar conditions (Santos-Silva et al., 2002). These values correspond to very tender meat (Sañudo et al., 2003), expressing the benefits of aging for 7 days under refrigerated conditions (Ripoll et al., 2012).

The major causes of the loss of quality of meat during conditioning are oxidation of lipids and myoglobin, namely by the development of unpleasant off-flavours, and by discoloration (Buckley, Morrissey, \& Gray, 1995). The $\Delta \mathrm{E}$ characterizes the global colour changes during meat storage (Mancini \& Hunt, 2005). In the present trial $\Delta \mathrm{E}$ was not affected by treatments and is comparable with those previously reported by Jerónimo et al. (2012) and Francisco et al. (2015) for Merino Branco LT with the same conditioning period. According to Abril et al.
(2001) such differences in colour are easily distinguishable by consumers.

The TBARS are a common index used to evaluate the oxidation status of meat and relate to the extent of FA oxidation, measuring the secondary oxidation product malonaldehyde. The average value obtained in this experiment $(1.28 \pm 0.508)$ is comparable with results obtained in meat of lambs fed high-concentrate diets, supplemented with PUFA-rich vegetable oil and processed and stored under the same condition (Francisco et al., 2015; Francisco et al., 2017). In our experiment, the level of PUFA in meat was similar for the three diets and could not contribute to differences in lipid oxidation. Campo et al. (2006), reported $2 \mathrm{mg} / \mathrm{kg}$ as a threshold value for TBAR for consumer acceptability of beef. In spite of between species differences, the values observed in our experiment were below $2 \mathrm{mg} / \mathrm{kg}$, suggesting the lamb maintained its eating quality 10 days after slaughter.

The fatty acid composition was evaluated in $\mathrm{ScF}$ and intramuscular fat of LT and the statistical model used revealed no significant interactions between diet and fat tissue. As expected, the ScF had lower proportions of SFA and PUFA, and higher proportion of cis-MUFA, BI and terminal and non terminal- BCFA compared to the LT (Costa et al., 2017). It is well established that there is a gradient in the melting point of fatty tissues related to body location, with lower values for external $\mathrm{ScF}$ when compared to intermuscular or visceral fat. The high proportion of BCFA in the ScF is in line with this general standard because it 
has been found to reduce melting point of the fat (Berthelot, Normand, Bas, \& Kristensen, 2001). Nevertheless, the proportion of nonterminalBCFA in ScF remained low and similar across diets, as reported and discussed by Costa et al. (2017).

The main objective of the experiment was to test the hypothesis that incorporating forage NDF into oil-supplemented finishing diets would have a differential effect on the deposition of BI in lamb meat, when compared to high digestible NDF from soybean hulls. Lambs fed ground dehydrated alfalfa diets supplemented with unsaturated vegetable oil, consistently display high proportions of desirable BI, like t11-18:1 and $c 9, t 11-18: 2$ in the rumen and meat (Alves, Santos-Silva, Cabrita, Fonseca, \& Bessa, 2013; Jerónimo et al., 2009; Jerónimo et al., 2010; Jerónimo et al., 2010; Santos-Silva et al., 2004). However, when finishing lambs with high starch diets, particularly if supplemented with oil, the pattern of BI deposited in tissues change, and the undesirable t10-18:1 accumulates (Bessa, Portugal, Mendes, \& Santos-Silva, 2005; Oliveira, Alves, Santos-Silva, \& Bessa, 2017). This change is due to an extensive shift in the rumen BH pathways, the $t 10$-shift, although its deleterious consequence on product quality is yet weakly understood (Bessa et al., 2015). In fact, such extensive alteration in rumen $\mathrm{BH}$ pathways must be the result of extensive changes in rumen microbiota, but the exact nature of such changes remains to be established (Enjalbert, Combes, Zened, \& Meynadier, 2017).

In a previous experiment, we fed lambs with low-starch and high oil diets, where cereals were replaced by industrial by-products. It was observed that a high NDF diet containing soybean hulls was not effective in preventing the t10-18:1 accumulation (Costa et al., 2017). Thus, we hypothesized that the rate of NDF degradation in the rumen should affect the rumen $\mathrm{BH}$ pathways, and that the reduction of forage NDF degradability rate could promote the $t 11-18: 1$ synthesis. The results presented here confirm that hypothesis as replacing soybean hulls NDF by alfalfa NDF in isoNDF diets led to a linear decrease of $t 10-18: 1$ and $t 10, c 12-18: 2$ (Alves \& Bessa, 2014; Bravo-Lamas, Barron, Kramer, Etaio, \& Aldai, 2016) and to a linear increase in t11-18:1 and $c 9, t 11-18: 2$. The $t 10 / t 11$ ratio decreased with dietary alfalfa level from 10.0 to 3.8 and from 7.8 to 2.5 in ScF and LT respectively, following a quadratic pattern. In spite of the $t 10-18: 1$ being the major BI intermediate present in the fat and meat of most of the lambs, the intensity of the $t 10$-shift was clearly reduced when the alfalfa proportion was increased in the diet, mainly from 200 to $400 \mathrm{~g} / \mathrm{kg}$.

In fact, in the present experiment and in that reported by Costa et al. (2017), the rumen $\mathrm{pH}$ was low and there was evidence of rumen parakeratosis lesions indicative of sustained low rumen $\mathrm{pH}$ during the experimental periods. In the present experiment, the dietary content of starch and sugar were low and similar between diets, thus the differences in rumen $\mathrm{pH}$ observed are probably related to differences in the rate of NDF fermentation and of cations exchange capacity of the dietary ingredients (Dijkstra et al., 2012). If the rumen $\mathrm{pH}$ is the main driver of the $t 10$-shift, then production strategies to avoid it must be directed to prevent low rumen $\mathrm{pH}$.

We report again the occurrence of $t 10$ shifted animals fed with lowstarch, high-NDF diets, as evaluated by $t 10 / t 11$ ratio in ScF and meat, confirming our previous results (Costa et al., 2017). Surprisingly, even the diet containing $600 \mathrm{~g} / \mathrm{kg}$ of alfalfa and no cereals was unable to avoid the $t 10$-shift in $66 \%$ of the lambs. However, in previous experiments, oil supplemented diets containing $500 \mathrm{~g} / \mathrm{kg}$ of dehydrated alfalfa did not induce $t 10$-shift in lambs (Francisco et al., 2017). In all of these experiments we used ground feed ingredients that might not promote enough salivation to ensure rumen $\mathrm{pH}$ buffering. Nevertheless, the critical need for dietary physically effective NDF is certainly associated with diet fermentability as when oil is used to supplement $100 \%$ ground alfalfa basal diets the $t 10 / t 11$ ratio in the rumen, abomasum and tissue of lambs is consistently very low (Alves, Santos-Silva, et al., 2013; Jerónimo, Alves, Dentinho, et al., 2010).

The difficulty in establishing consistent response patterns between dietary components (like starch, sugar or NDF) and the occurrence of t10-shift reinforces the hypothesis that low rumen $\mathrm{pH}$ is the main driving force determining the establishment of the $t 10$-shift. In fact, in the present experiment and in that reported by Costa et al. (2017), the rumen $\mathrm{pH}$ was low and there was evidence of rumen parakeratosis lesions indicative of sustained low rumen $\mathrm{pH}$ during the experimental periods. In the present experiment, the dietary content of starch and sugar were low and similar between diets, thus the differences in rumen $\mathrm{pH}$ observed are probably related to differences in the rate of NDF fermentation and of cation exchange capacity of the dietary ingredients (Dijkstra et al., 2012). If the rumen $\mathrm{pH}$ is the main driver of the $t 10$ shift, then production strategies to avoid it must be directed to prevent low rumen $\mathrm{pH}$.

One of the consequences of the $t 10$-shift in ruminants is the low concentration of $c 9, t 11-18: 2$ in meat, even in animals fed oil supplemented diet (Bessa et al., 2015; Oliveira et al., 2016, 2017). This is clearly demonstrated in the present experiment, as diet LA presents a very low $c 9, t 11-18: 2$ proportion in ScF and meat $(0.48$ and $0.35 \mathrm{~g}$ / $100 \mathrm{~g}$ FA respectively), and increased with dietary alfalfa inclusion following the well established linear relationship with the $t 11-18: 1$ proportion (Palmquist, St-Pierre, \& McClure, 2004).

Besides the effects on BI, increasing alfalfa proportion in the diet led to a linear decrease in 16:0 and a linear increase the 18:2 n-6 despite the fact that the intake of $16: 0$ and 18:2 n-6 being similar among treatments. The $16: 0$ is the major end product of the endogenous de novo FA synthesis, and that finding might indicate a slight stimulation of those pathways in lambs fed soybean hulls compared to alfalfa, although not reflected in the amount of intramuscular lipid and FA content.

The linear increase of $18: 2 n-6$, coupled with the absence of effects on 18:0 and on the sum of BI, suggest that the BH of 18:2n- 6 was reduced as alfalfa was incorporated in the diet, and likely in part related to increased DM intake and rumen passage rate.

\section{Conclusions}

The BI pattern of meat and ScF was affected by the composition and structure of the fibrous fraction in complete diets for lambs. Increasing the proportion of alfalfa, and thus of ADL, in the diet, did not compromise growth performance and carcass and meat quality, but depressed the intensity of the $t 10$-shift following a quadratic pattern. Forty percent of alfalfa in diet reduced the severity of $t 10$-shift, but for its full resolution other factors should be considered including forage particle size and the buffering capacity of the diet.

\section{Funding}

This project was supported by European Fund for Regional Development (ERDF) [ALT20-03-0145-FEDER-000040 ValRuMeat Valorização da carne de ruminantes em sistemas intensivos de produção]. The authors would also like to thank Fundação para a Ciência e a Tecnologia (FCT) through research grant to SPA (SFRH/ BPD/76836/2011) and through the UID/CVT/00276/2013 Project.

\section{Acknowledgments}

The authors would like to thank to the INIAV staff of Fonte Boa, namely to António Sequeira and Suzete Gaudêncio for the support in animal management, to Paula Santos, for the support in slaughter and carcass evaluation and to José Batista for the chemical analysis.

\section{References}

Abril, M., Campo, M. M., Önenç, A., Sañudo, C., Albertí, P., \& Negueruela, A. I. (2001). Beef colour evolution as a function of ultimate pH. Meat Science, 58, 69-78. https:// doi.org/10.1016/S0309-1740(00)00133-9.

Alves, S. P., \& Bessa, R. J. B. (2009). Comparison of two gas-liquid chromatograph columns for the analysis of fatty acids in ruminant meat. Journal of Chromatography A, 
1216, 5130-5139.

Alves, S. P., \& Bessa, R. J. B. (2014). The trans-10,cis-15 18:2: A missing intermediate of trans-10 shifted rumen biohydrogenation pathway? Lipids, 49(6), 527-541. https:// doi.org/10.1007/s11745-014-3897-4.

Alves, S. P., Bessa, R. J. B., Quaresma, M. A. G., Kilminster, T., Scanlon, T., Oldham, C., .. Almeida, A. M. (2013). Does the fat tailed damara ovine breed have a distinct lipid metabolism leading to a high concentration of branched chain fatty acids in tissues? PLoS One, 8(10), e77313. https://doi.org/10.1371/journal.pone.0077313.

Alves, S. P., Santos-Silva, J., Cabrita, A. R. J., Fonseca, A. J. M., \& Bessa, R. J. B. (2013). Detailed dimethylacetal and fatty acid composition of rumen content from lambs fed lucerne or concentrate supplemented with soybean oil. PLoS One, 8(3), e58386. https://doi.org/10.1371/journal.pone.0058386.

AMSA (2012). Meat Color measurement guidelines. Champaign, Illinois USA: American Meat Science Association.

AMSA (2015). Research guidelines for cookery, sensory evaluation, and instrumental tenderness measurements of meat (Second ed.). Champaign, Illinois, USA: American Meat Science Association.

Berthelot, V., Normand, J., Bas, P., \& Kristensen, N. B. (2001). Softness and fatty acid composition of subcutaneous adipose tissue, and methylmalonic acid concentrations in the plasma of intensively reared lambs. Small Ruminant Research, 41(1), 29-38. https://doi.org/10.1016/S0921-4488(01)00190-0.

Bessa, R. J. B., Alves, S. P., \& Santos-Silva, J. (2015). Constraints and potentials for the nutritional modulation of the fatty acid composition of ruminant meat. European Journal of Lipid Science and Technology, 117, 1325-1344. https://doi.org/10.1002/ ejlt.201400468.

Bessa, R. J. B., Portugal, P. V., Mendes, I. A., \& Santos-Silva, J. (2005). Effect of lipid supplementation on growth performance, carcass and meat quality and fatty acid composition of intramuscular lipids of lambs fed dehydrated lucerne or concentrate. Livestock Production Science, 96(2), 185-194. https://doi.org/10.1016/j.livprodsci. 2005.01.017.

Bravo-Lamas, L., Barron, L. J. R., Kramer, J. K. G., Etaio, I., \& Aldai, N. (2016). Characterization of the fatty acid composition of lamb commercially available in northern Spain: Emphasis on the trans-18:1 and CLA content and profile. Meat Science, 117, 108-116. https://doi.org/10.1016/j.meatsci.2016.02.043.

Buckley, D. J., Morrissey, P. A., \& Gray, J. I. (1995). Influence of dietary vitamin E on the oxidative stability and quality of pig meat. Journal Animal Science, 73, 3122-3130. https://doi.org/10.1542/pir.31-10-438.

Campo, M. M., Nute, G. R., Hughes, S. I., Enser, M., Wood, J. D., \& Richardson, R. I. (2006). Flavour perception of oxidation in beef. Meat Science, 72(2), 303-311. https://doi.org/10.1016/j.meatsci.2005.07.015.

Chikwanha, O. C., Vahmani, P., Muchenje, V., Dugan, M. E. R., \& Mapiye, C. (2018) Nutritional enhancement of sheep meat fatty acid profile for human health and wellbeing. Food Research International, 104, 25-38. https://doi.org/10.1016/j. foodres.2017.05.005.

Choi, N. J., Imm, J. Y., Oh, S., Kim, B. C., Hwang, H. J., \& Kim, Y. J. (2005). Effect of pH and oxygen on conjugated linoleic acid (CLA) production by mixed rumen bacteria from cows fed high concentrate and high forage diets. Animal Feed Science and Technology, 123-124 PA, 643-653. https://doi.org/10.1016/j.anifeedsci.2005.04. 054.

Costa, M., Alves, S. P., Francisco, A., Almeida, J., Alfaia, C. M., Martins, S. V., ... Bessa, R. J. B. (2017). The reduction of starch in finishing diets supplemented with oil does not prevent the accumulation of trans-10 18:1 in lamb meat1. Journal of Animal Science, 95(8), 3745-3761. https://doi.org/10.2527/jas.2017.1578.

Dijkstra, J., Ellis, J. L., Kebreab, E., Strathe, A. B., Lopez, S., France, J., \& Bannink, A. (2012). Ruminal $\mathrm{pH}$ regulation and nutritional consequences of low $\mathrm{pH}$. Animal Feed Science and Technology, 172(1-2), 22-33. https://doi.org/10.1016/j.anifeedsci.2011. 12.005 .

DIRECTIVE 2010/63/EU OF THE EUROPEAN PARLIAMENT AND OF THE COUNCIL of 22 (2010). September 2010 on the protection of animals used for scientific purposes $\S \mathrm{L}$ 276.

EC (2011). In E. Commission (Ed.). Community scale for the classification of carcasses of ovine animalsLuxembourg: Office for Official Publications Of European Communities KF-31-10-388-EN-D.

Enjalbert, F., Combes, S., Zened, A., \& Meynadier, A. (2017). Rumen microbiota and dietary fat: a mutual shaping. Journal of Applied Microbiology, 123(4), 782-797. https://doi.org/10.1111/jam.13501.

Folch, J., Lees, M., \& Stanley, G. H. S. (1957). Simple method for the isolation and purification of total lipids from animal tissues. The Journal of Biological Chemistry, 226, 497-509.

Francisco, A., Alves, S. P., Portugal, P. V., Dentinho, M. T., Jerónimo, E., Sengo, S., .. Santos-Silva, J. (2017). Effects of dietary inclusion of citrus pulp and rockrose soft stems and leaves on lamb meat quality and fatty acid composition. Animal, 1-10. https://doi.org/10.1017/S1751731117002269.

Francisco, A., Dentinho, M. T., Alves, S. P., Portugal, P. V., Fernandes, F., Sengo, S., ... Santos-Silva, J. (2015). Growth performance, carcass and meat quality of lambs supplemented with increasing levels of a tanniferous bush (Cistus ladanifer L.) and vegetable oils. Meat Science, 100, 275-282. https://doi.org/10.1016/j.meatsci.2014. 10.014 .

Grau, A., Guardiola, F., Boatella, J., Barroeta, A., \& Cordony, R. (2000). Measurement of 2-thiobarbituric acid values in dark chiken meat through derivative spectrophotometry: influence of various parameters. Journal of Agriculture and Food Chemistry, 48, 1155-1159.

Griinari, J. M., \& Bauman, D. E. (2001). Production of low fat milk by diet induced milk fat depression Advances in Dairy technology. Vol. 13, 197-212.

Hodgson, J. M., Wahlqvist, M. L., Boxall, J. A., \& Balazs, N. D. (1996). Platelet trans fatty acids in relation to angiographically assessed coronary artery disease. Atherosclerosis, 120, 147-154. https://doi.org/10.1016/0021-9150(95)05696-3.

Jerónimo, E., Alfaia, C. M. M., Alves, S. P., Dentinho, M. T. P., Prates, J. A. M., Vasta, V., Bessa, R. J. B. (2012). Effect of dietary grape seed extract and Cistus ladanifer L in combination with vegetable oil supplementation on lamb meat quality. Meat Science,
92, 841-847. https://doi.org/10.1016/j.meatsci.2012.07.011.

Jerónimo, E., Alves, S. P., Dentinho, M. T. P., Martins, S. V., Prates, J. A. M., Vasta, V., ... Bessa, R. J. B. (2010). Effect of grape seed extract, Cistus ladanifer L., and Vegetable oil supplementation on fatty acid composition of abomasal digesta and intramuscular fat of lambs. Journal of Agricultural and Food Chemistry, 58, 10710-10721. https:// doi.org/10.1021/jf1021626.

Jerónimo, E., Alves, S. P., Martins, S. V., Prates, J. A. M., Bessa, R. J. B., \& Santos-Silva, J. (2010). Effect of sodium bentonite and vegetable oil blend supplementation on growth, carcass quality and intramuscular fatty acid composition of lambs. Animal Feed Science and Technology, 158(3-4), 136-145. https://doi.org/10.1016/j. anifeedsci.2010.04.010.

Jerónimo, E., Alves, S. P., Prates, J. A. M., Santos-Silva, J., \& Bessa, R. J. B. (2009). Effect of dietary replacement of sunflower oil with linseed oil on intramuscular fatty acids of lamb meat. Meat Science, 83, 499-505. https://doi.org/10.1016/j.meatsci.2009. 06.033 .

Khliji, S., van de Ven, R., Lamb, T. A., Lanza, M., \& Hopkins, D. L. (2010). Relationship between consumer ranking of lamb colour and objective measures of colour. Meat Science, 85, 224-229. https://doi.org/10.1016/j.meatsci.2010.01.002.

Kleen, J. L., Hooijer, G. A., Rehage, J., \& Noordhuizen, J. P. T. M. (2003). Subacute ruminal acidosis (SARA): a review. Journal of Veterinary Medicine Series a-Physiology Pathology Clinical Medicine, 50(8), 406-414. https://doi.org/10.1046/j.1439-0442. 2003.00569.x.

Maia, M. R. G., Bessa, R. J. B., \& Wallace, R. J. (2009). Is the trans-10 shift that sometimes occurs in ruminal biohydrogenation of linoleic acid caused by low $\mathrm{pH}$ or starch? (A Rusitec study. Paper presented at the XI th International Symposium of Ruminal Physiology Clermont-Ferrand).

Mancini, R. A., \& Hunt, M. C. (2005). Current research in meat color. Meat Science, 71, 100-121. https://doi.org/10.1016/j.meatsci.2005.03.003.

Mapiye, C., Vahmani, P., Mlambo, V., Muchenje, V., Dzama, K., Hoffman, L. C., \& Dugan, M. E. R. (2015). The trans-octadecenoic fatty acid profile of beef: Implications for global food and nutrition security. Food Research International, 76, 992-1000. https:// doi.org/10.1016/j.foodres.2015.05.001.

Nozière, P., Graulet, B., Lucas, A., Martin, B., Grolier, P., \& Doreau, M. (2006). Carotenoids for ruminants: From forages to dairy products. Animal Feed Science and Technology, 131(3), 418-450. https://doi.org/10.1016/j.anifeedsci.2006.06.018.

Oliveira, M. A., Alves, S. P., Santos-Silva, J., \& Bessa, R. J. B. (2016). Effects of clays used as oil adsorbents in lamb diets on fatty acid composition of abomasal digesta and meat. Animal Feed Science and Technology, 213, 64-73. https://doi.org/10.1016/j. anifeedsci.2016.01.006.

Oliveira, M. A., Alves, S. P., Santos-Silva, J., \& Bessa, R. J. B. (2017). Effect of dietary starch level and its rumen degradability on lamb meat fatty acid composition. Meat Science, 123, 166-172. https://doi.org/10.1016/j.meatsci.2016.10.001.

Palmquist, D. L., St-Pierre, N., \& McClure, K. E. (2004). Tissue fatty acid profiles can be used to quantify endogenous rumenic acid synthesis in lambs. Journal of Nutrition, 134(9), 2407-2414.

Priolo, A., Micol, D., \& Agabriel, J. (2001). Effects of grass feeding systems \non ruminant meat colour and flavour. A review. Animal Research, 50, 185-200. https://doi.org/10. 1051/animres: 2001125.

Raes, K., De Smet, S., \& Demeyer, D. (2004). Effect of dietary fatty acids on incorporation of long chain polyunsaturated fatty acids and conjugated linoleic acid in lamb, beef and pork meat: A review. Animal Feed Science and Technology, 113, 199-221. https:// doi.org/10.1016/j.anifeedsci.2003.09.001.

Ripoll, G., Albertí, P., \& Joy, M. (2012). Influence of alfalfa grazing-based feeding systems on carcass fat colour and meat quality of light lambs. Meat Science, 90(2), 457-464. https://doi.org/10.1016/j.meatsci.2011.09.007.

Santos-Silva, J., Bessa, R. J. B., \& Santos-Silva, F. (2002). Effect of genotype, feeding system and slaughter weight on the quality of light lambs. I. Growth, carcass composition and meat quality. Livestock Production Science, 77, 187-194. https://doi.org/ 10.1016/S0301-6226(02)00059-3.

Santos-Silva, J., Dentinho, M. T., Francisco, A., Belo, A. T., Martins, A. P. L., Alves, S. P., \& Bessa, R. J. B. (2016). Replacing cereals with dehydrated citrus pulp in a soybean oil supplemented diet increases vaccenic and rumenic acids in ewe milk. Journal of Dairy Science, 99, 1173-1182. https://doi.org/10.3168/jds.2015-9966.

Santos-Silva, J., Mendes, I. A., Portugal, P. V., \& Bessa, R. J. B. (2004). Effect of particle size and soybean oil supplementation on growth performance, carcass and meat quality and fatty acid composition of intramuscular lipids of lambs. Livestock Production Science, 90(2), 79-88. https://doi.org/10.1016/j.livprodsci.2004.02.013.

Sañudo, C., Alfonso, M., Sanchez, A., Berge, P., Dransfield, E., Zygoyiannis, D., ... Fischer, A. V. (2003). Meat texture of lambs from different European production systems. Australian Journal of Agricultural Research, 54(6), 551-560. doi: https://doi.org/10. 1071/AR02092

Sauvant, D., Chapoutot, P., Peyraud, J.-L., Meschy, F., \& Doreau, B. (2002). Valeurs nutritives pour les ruminants. In D. Sauvant, J.-M. Perez, \& G. Tran (Eds.). Tables des compositions et de valeur nutritives des matières premières destinées aux animaux d'élevage (pp. 43-50). Paris: INRA.

Scollan, N. D., Dannenberger, D., Nuernberg, K., Richardson, I., MacKintosh, S., Hocquette, J. F., \& Moloney, A. P. (2014). Enhancing the nutritional and health value of beef lipids and their relationship with meat quality. Meat Science, 97, 384-394. https://doi.org/10.1016/j.meatsci.2014.02.015.

Tamate, H., Nagatani, T., Yoneya, S., Sakata, T., \& Miura, J. (1973). High incidence of ruminal lesions and liver abcess in the beef associated with intensive fattening in Miyagi Prefecture. Tohoku Journal of Agricultura Research, 23(4), 184-195.

Vahmani, P., Rolland, D. C., Gzy, L. K. E., \& Dugan, M. E. R. (2016). Non-conjugated cis/ trans 18:2 in Beef Fat are Mainly $\Delta-9$ Desaturation Products of trans-18:1 Isomers. Lipids, 51, 1427-1433.

Zened, A., Enjalbert, F., Nicot, M. C., \& Troegeler-Meynadier, A. (2013). Starch plus sunflower oil addition to the diet of dry dairy cows results in a trans-11 to trans-10 shift of biohydrogenation. Journal of Dairy Science, 96, 451-459. https://doi.org/10. 3168/jds.2012-5690. 